\title{
Did they Define the Outcome? Churches and the Independence Referendum in Scotland
}

\section{In: J ournal of Religion in Europe}

Author: Sergei A. Mudrovi

- ${ }^{1}$ Visiting Fellow, Global Dialogues Fellowship of the "Artes Liberales Institute" Foundation, University of Warsaw, Poland, mudrov@al.uw.edu.pl

Online Publication Date:

16 pr 2018

\section{Abstract}

The 2014 referendum in Scotland, which brought victory for the unionists, was characterised by a high level of involvement of religious organisations in the campaign. Although the Churches chose to be neutral on the referendum dilemma, this was explained by prevailing attitudes among clergy, who objected Scottish independence. In this article, analysing the stance of the Church of Scotland, Roman Catholic Church, Episcopal Church of Scotland, and Free Church of Scotland, I argue that the chosen path of neutrality played more in favour of unionists. The Churches' influence on the referendum's outcome was far beyond statistical errors, and had Churches publicly supported independence, it would have been likely that Edinburgh would now be negotiating the terms of "divorce" with London.

Metadata

Title: 
Did they Define the Outcome? Churches and the Independence Referendum in Scotland Article Type:

Research Article

\section{DOI:}

https:/ / doi.org/ 10.1163/ 18748929-01101002

Language:

English

Pages:

$$
20-45
$$

Keywords:

Churches; Scotland; religion; independence; referendum In:

In:

J ournal of Religion in Europe

Volume 11: Issue 1

Publisher:

Brill

E-ISSN:

1874-8929

Print ISSN:

1874-8910

Subjects:

History of Religion, Religious Studies, Religion \&

Society, Social Sciences, Religion, Middle East and

Islamic Studies, Anthropology of Religion, Comparative

Religion \& Religious Studies 


\section{References}

Chrysostomos Archbishop (2011) "The head of the Church of Cyprus said that the country should leave the European Union". Available at: http:/ / survincity.com/ 2011/ 10/ thehead-of-the-church-of-cyprus-said-that-the/ Date of access:

27.01.2017.

- Search Google Scholar

- Export Citation

- \ulcorner

Bergin Claire (2014) "Scotland: More than 30 Kirk ministers join Christian Yes' campaign". Available at: http:// www.indcatholicnews.com/ news.php?viewStory=2 5461Date of access: 27.01.2017.

- Search Google Scholar

- Export Citation

- \ulcorner

Bonney Norman (2013) "Religion and the Scottish Independence Referendum". The Political Quarterly, Vol. 84, No. 4, pp. 478- 485 .

- Search Google Scholar

- Export Citation

- ᄃ

Bradley Ian (2014) 'Two kings and two kingdoms: the Church of Scotland, the monarchy, national identity and establishment". International journal for the Study of the Christian Church. 14:2, pp. 156- 174.

- Search Google Scholar

- Export Citation

- ᄃ 
Brown David (2014) "Scotland: religion, culture and national identity". International journal for the Study of the Christian Church. 14:2, pp. 88-99.

- Search Google Scholar

- Export Citation

- ᄃ

Bruce Steve (2013) 'Post-Secularity and Religion in Britain: An Empirical Assessment.' J ournal of Contemporary Religion 28 (3), pp. 369-384.

- Search Google Scholar

- Export Citation

- \ulcorner

Casanas Adam Elisenda (2014) "Self-determination and the Use of Referendums: the Case of Scotland". Int J ournal Polit Cult Soc, 27, pp. 47- 66.

- Search Google Scholar

- Export Citation

. ᄃ

Chillingworth David (2014) "Churches agnostic on independence". Available at: https:/ / www.churchtimes.co.uk/ articles/ 2014/ 14march/ comment/ opinion/ churches-agnostic-onindependenceDate of access: 27.02.2017.

- Search Google Scholar

- Export Citation

- \ulcorner

Church of England (1972) "November 1972 General Synod Motion On Europe". Available at: http:/ / www.cofe.anglican.org/ info/ socialpublic/ internatio nal/ europe/ europegsreport.docDate of access: 27.01.2017.

- Search Google Scholar 
- Export Citation

- ᄃ

Church of Scotland (2014) "Minutes of the Proceedings of the General Assembly of the Church of Scotland". Available at: http:/ / www.churchofscotland.org.uk/__ data/assets/pdf_f ile/ 0006/ 21102/ Assembly-Minutes-Thurs-2014.pdfDate of access: 27.01.2017.

- Search Google Scholar

- Export Citation

- ᄃ

Church of Scotland (N.d.) "10,000 voices for change". Available at: http:/ / www.churchofscotland.org.uk/ speak_out/ 10000_v oicesDate of access: 27.01.2017.

- Search Google Scholar

- Export Citation

- \ulcorner

Church of Scotland (N.d.a) "Our vision. Imagining Scotland's future". Available at: http:// www.churchofscotland.org.uk/__ data/ assets/pdf_f ile/ 0019/ 23185/ ISF-for-web.pdfDate of access: 27.01.2017.

- Search Google Scholar

- Export Citation

- \ulcorner

Church of Scotland (2015) "Living stones. Annual Report and Accounts 2014". Available at: http:/ / www.churchofscotland.org.ulk/_ data/assets/pdf f ile/ 0003/ 27327/ annual_report.pdfDate of access: 27.01.2017.

- Search Google Scholar

- Export Citation

- 
Church of Scotland (2015a) "Minutes of the Proceedings of the General Assembly of the Church of Scotland". Available at: http:/ / www.churchofscotland.org.ulk/_ data/ assets/pdf_f ile/ 0004/27670/ga_minutes_tuesday_19.'pdfDate of access: 27.01.2017.

- Search Google Scholar

- Export Citation

- $匚$

Church of Scotland (2015b) "Outgoing Moderator calls for unity". Available

at: http:/ / www.churchofscotland.org.uk/ news_and_events/ $\mathrm{n}$ ews/recent/ outgoing_moderator_calls_for unity_and_recon ciliationDate of access: 27.01.2017.

- Search Google Scholar

- Export Citation

- \ulcorner

Cushley Leo (2014) "Would the moral consensus be any different in an independent Scotland?" Available at: http:/ / www.scmo.org/ index.php?page=briefings\&article= archbishop-leo-cushley-opinio\&perma=1403435811Date of access: 27.01.2017.

- Search Google Scholar

- Export Citation

- \ulcorner

Dunlop Martin (N.d.) 'Will independence fuel sectarianism?" Available at: http:/ / www.sconews.co.uk/ news/ 11903/ willindependence-fuel-sectarianism/ Date of access: 27.01.2017.

- Search Google Scholar

- Export Citation

. 
Forbes J ohn (2014) 'The referendum-What they don't tell you in the news". Available at: http:/ / freechurch.org/ news/ the-referendum-what-theydont-tell-you-in-the-newsDate of access: 27.01.2017.

- Search Google Scholar

- Export Citation

- \ulcorner

Fraser Douglas (2015) "Study examines referendum demographics". Available at: http:/ / www.bbc.com/news/ ukscotland-glasgow-west-34283948Date of access: 27.01.2017.

- Search Google Scholar

- Export Citation

- \ulcorner

Free Church of Scotland (2014) "Churchmen consider independence referendum arguments". Available at: http:/ / freechurch.org/ news/ churchmen-consider-indyrefargumentsDate of access: 27.01.2017.

- Search Google Scholar

- Export Citation

- $匚$

Free Presbyterian Church of Scotland (2014) "Scottish

Independence-Synod says Vote No"'. Available at: http:/ / www.fpchurch.org.uk/ 2014/ 07/ scottishindependence-referendum-synod-resolution/ Date of access: 27.01.2017.

- Search Google Scholar

- Export Citation

- \ulcorner

Gillies Robert (2014) “Respect other people’s identities". Available at: http:/ / www.scotland.anglican.org/ wp- 
content/ uploads/ 2014/ 03/ Respect-other-peoples-

identities.pdfDate of access: 27.01.2017.

- Search Google Scholar

- Export Citation

- $г$

Goldie Annabel (2015). Interview with SCPO. Available at: http:/ / www.actsparl.org/ media/ 205643/ baroness\%20ann abel\%20goldie\%20msp.pdfDate of access: 27.01.2017.

- Search Google Scholar

- Export Citation

-

Guibernau Montserrat, Rocher Francois and Adam Elisenda Casanas (2014) Introduction: A Special Section on SelfDetermination and the Use of Referendums: Catalonia, Quebec and Scotland'. Int J ournal Polit Cult Soc, 27, 1- 3.

- Search Google Scholar

- Export Citation

- ᄃ

Hamerly Ivy (2012) "Christian Democratic Parties and the Domestic Parliamentary Response to European Integration". J ournal of Church and State, Vol. 54, No. 2, pp. 214-239.

- Search Google Scholar

- Export Citation

- ᄃ

Harkins Daniel (2014) "Scotland's archbishops urge Catholics to vote in independence referendum". Available at: http:/ / www.sconews.co.ulk/ news/ 39575/ scotlandsarchbishops-urge-catholics-to-vote-in-independencereferendum/ Date of access: 27.01.2017.

- Search Google Scholar 
- Export Citation

- \ulcorner

Hassan Gerry (2014) "State of independence: the rise of third Scotland"'. Soundings,

- Search Google Scholar

- Export Citation

- \ulcorner

Life and Work Magazine (2014) "Church to host new referendum debate". Available at: http:/ / www.lifeandwork.org/ news/ news/ post/ 260church-to-host-new-referendum-debateDate of access: 27.01.2017.

- Search Google Scholar

- Export Citation

- ᄃ

Life and Work Magazine (2015) "Moderator Launches EU Referendum Blog". Available at: http:/ / www.lifeandwork.org/ news/ news/ post/ 466moderator-launches-eu-referendum-blogDate of access: 27.01.2017.

- Search Google Scholar

- Export Citation

. ᄃ

Mason Roger (2013) “Dis-United Kingdoms? What Lies Behind Scotland's Referendum on Independence". Georgetown J ournal of International Affairs, Summer/ Fall, pp. 139- 146.

- Search Google Scholar

- Export Citation

- ᄃ 
McOwan Rennie (2014) "A central, moral issue in referendum". Available

at: http:/ / www.sconews.co.uk/ opinion/ 40023/ 40023/ Date of access: 27.01.2017.

- Search Google Scholar

- Export Citation

- $匚$

Mudrov Sergei (2015) "Religion and the European Union: Attitudes of Catholic and Protestant Churches toward

European Integration". J ournal of Church and State, Vol. 57, No. 3. pp. 507-528.

- Search Google Scholar

- Export Citation

- ᄃ

Mudrov Sergei (2016) "Religion in the Treaty of Lisbon:

Aspects and Evaluation". J ournal of Contemporary Religion, Vol. 31, Issue 1, pp. 1- 16.

- Search Google Scholar

- Export Citation

- \ulcorner

Mullen Tom (2014) "The Scottish Independence Referendum 2014". J ournal of Law and Society, Volume 41, Number 4, pp. 627-640.

- Search Google Scholar

- Export Citation

- \ulcorner

B. Nelsen , J . Guth and Ch. Fraser (2001) “Does Religion Matter? Christianity and Public Support for the European Union”. European Union Politics, Vol. 2(2), pp. 191- 217.

- Search Google Scholar

- Export Citation 
Ross J ohn (2014) "Church Establishment in an Independent Scotland".

- Search Google Scholar

- Export Citation

- \ulcorner

Stoddart Eric (2014) "Public Practical Theology in Scotland:

with particular reference to the independence

referendum". International J ournal of Practical

Theology, 18(2), pp. 317- 347.

- Search Google Scholar

- Export Citation

- ᄃ

STV (2014) "Church of Scotland group pledges support for Scottish independence". Available

at: http:/ / news.stv.tv/ scotland-decides/ 289507-church-ofscotland-group-pledges-support-for-scottishindependence/ Date of access: 27.01.2017.

- Search Google Scholar

- Export Citation

- \ulcorner

Thompson Damian (2014) "The Scottish Catholic bishops and the Nationalists: a scandal is coming to light". Available at: http:/ / blogs.spectator.co.uk/ 2014/ 09/ the-scottishcatholic-bishops-and-the-nationalists-a-scandal-is-comingto-light/ Date of access: 27.01.2017.

- Search Google Scholar

- Export Citation

- ᄃ 
Tierney Stephen (2013) "Legal Issues Surrounding the Referendum on Independence for Scotland". European

Constitutional Law Review, 9, pp. 359- 390.

- Search Google Scholar

- Export Citation

- ᄃ

Torrance David (2013) "The Battle for Britain. Scotland and the Independence Referendum”. Biteback

Publishing, London.

- Search Google Scholar

- Export Citation

- ᄃ

Torrance David (2014) "100 Days of Hope and Fear. How Scotland's Independence Referendum was Lost and Won". Luath Press Limited, Edinburgh.

- Search Google Scholar

- Export Citation

- ᄃ

The Russian Orthodox Church. Department for External Church Relations (N.d.). Available at: https:// mospat.ru/ en/ documents/ socialconcepts/ xvi/ Date of access: 27.01.2017.

- Search Google Scholar

- Export Citation

- \ulcorner

The Scottish Government (2013) "Scotland's Future. Executive Summary". Available at: http:/ / www.gov.scot/ scotlandsfutureDate of access: 27.01.2017.

- Search Google Scholar

- Export Citation 
The Scottish Government (2013a) "Scotland's Future. Your guide to an independent Scotland". Available at: http:// www.gov.scot/ Resource/ 0043/ 00439021.pdfDate of access: 27.01.2017.

- Search Google Scholar

- Export Citation

- $匚$

Vogan Matthew (2014) "Referendum result—a call to thanksgiving". Available at: http:/ / www.fpchurch.org.uk/ 2014/ 09/ referendum-resulta-call-to-thanksgiving/ Date of access: 27.01.2017.

- Search Google Scholar

- Export Citation

- $ᄃ$

Interview with Arnold 2015. Interview with BishopJ ohn Arnold, Diocese of Salford. Manchester, 29.04.2015.

Interview with Catholic priest 2015. Interview with Catholic priest, Glasgow, 16.03.2015.

Interview with Chillingworth 2015. Interview with David Chillingworth, Primus of the Episcopal Church of Scotland. Perth, Scotland, 14.04.2015.

- \ulcorner

Interview with Foster-Fulton 2015. Interview with Sally Foster-Fulton, Convener of the Church and Society Council of the Church of Scotland. 24.03.2015. 
Interview with Gay 2015. Interview with Douglas Gay, Church of Scotland minister and Lecturer at the University of

Glasgow. Glasgow, 21.04.2015.

Interview with Keenan 2015. Interview with Kevin Keenan, Scottish Labour Party Councillor in Dundee City Council. Dundee, 22.04.2015.

Interview with Mackenzie 2015. Interview with Peter

Mackenzie, Scottish National Party councillor in East Lothian Council. Edinburgh, 19.03.2015.

Interview with Robertson 2015. Interview with David

Robertson, minister of St Peter's Church, moderator of Free

Church of Scotland in 2015- 2016. Dundee, 27.03.2015.

E-mail correspondence with Ross. E-mail correspondence with J ohn Ross, Free Church of Scotland minister for Glenurquhart and Fort Augustus. 16.04.2015.

Interview with Shanks 2015. Interview with Norman Shanks, former convener of the Church and Nation Committee of the Church of Scotland. Glasgow, 21.04.2015.

Interview with Thompson 2015. Interview with Dave Thompson. Member of Scottish Parliament, Convener of the “Christians for Independence” group. Edinburgh, 19.03.2015. 
Interview with Toal 2015. Interview with Bishop J oseph Toal, Diocese of Motherwell. Motherwell, 16.03.2015.

Interview with Treanor 2015. Interview with Bishop Noel

Treanor, Diocese of Down and Connor. Belfast, 06.03.2015.

Interview with Wilson 2015. Interview with J ames Wilson, Clerk of Dundee Presbytery. Dundee, 26.03.2015. 